\title{
Front Matter: Volume 9564
}

, "Front Matter: Volume 9564," Proc. SPIE 9564, Light Manipulating Organic Materials and Devices II, 956401 (22 October 2015); doi: 10.1117/12.2218481

Event: SPIE Organic Photonics + Electronics, 2015, San Diego, California, United States 


\section{PROCEEDINGS OF SPIE}

\section{Light Manipulating Organic Materials and Devices II}

Jon A. Schuller

Editor

10-13 August 2015

San Diego, California, United States

Sponsored and Published by

SPIE 
The papers in this volume were part of the technical conference cited on the cover and title page. Papers were selected and subject to review by the editors and conference program committee. Some conference presentations may not be available for publication. Additional papers and presentation recordings may be available online in the SPIE Digital Library at SPIEDigitallibrary.org.

The papers reflect the work and thoughts of the authors and are published herein as submitted. The publisher is not responsible for the validity of the information or for any outcomes resulting from reliance thereon.

Please use the following format to cite material from these proceedings:

Author(s), "Title of Paper," in Light Manipulating Organic Materials and Devices II, edited by Jon A. Schuller, Proceedings of SPIE Vol. 9564 (SPIE, Bellingham, WA, 2015) Six-digit Article CID Number.

ISSN: 0277-786X

ISSN: 1996-756X (electronic)

ISBN: 9781628417302

Published by

SPIE

P.O. Box 10, Bellingham, Washington 98227-0010 USA

Telephone +1 3606763290 (Pacific Time) · Fax +1 3606471445

SPIE.org

Copyright (C) 2015, Society of Photo-Optical Instrumentation Engineers.

Copying of material in this book for internal or personal use, or for the internal or personal use of specific clients, beyond the fair use provisions granted by the U.S. Copyright Law is authorized by SPIE subject to payment of copying fees. The Transactional Reporting Service base fee for this volume is $\$ 18.00$ per article (or portion thereof), which should be paid directly to the Copyright Clearance Center (CCC), 222 Rosewood Drive, Danvers, MA 01923. Payment may also be made electronically through CCC Online at copyright.com. Other copying for republication, resale, advertising or promotion, or any form of systematic or multiple reproduction of any material in this book is prohibited except with permission in writing from the publisher. The CCC fee code is 0277-786X/15/\$18.00.

Printed in the United States of America.

Publication of record for individual papers is online in the SPIE Digital Library.

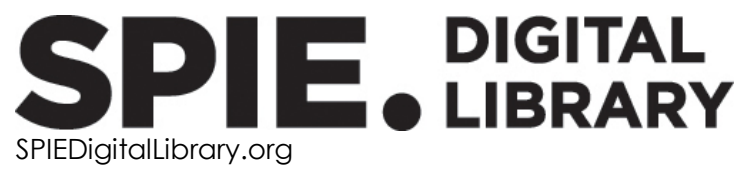

Paper Numbering: Proceedings of SPIE follow an e-First publication model. A unique citation identifier (CID) number is assigned to each article at the time of publication. Utilization of CIDs allows articles to be fully citable as soon as they are published online, and connects the same identifier to all online and print versions of the publication. SPIE uses a six-digit CID article numbering system structured as follows:

- The first four digits correspond to the SPIE volume number.

- The last two digits indicate publication order within the volume using a Base 36 numbering system employing both numerals and letters. These two-number sets start with 00, 01, 02, 03, 04, 05, 06, 07, 08, 09, OA, OB ... OZ, followed by 10-1Z, 20-2Z, etc. The CID Number appears on each page of the manuscript. 


\title{
Contents
}

\author{
$\checkmark$ Authors \\ vii Conference Committee
}

EXCITON-POLARITONS AND ORGANIC PLASMONICS

956406 Optical properties of cellulose nanocrystals decorated with silver nanospheres (Invited Paper) [9564-5]

NONLINEAR PROCESSES AND MATERIALS

956407 Universal scaling in nonlinear optical molecules (Invited Paper) [9564-6]

956408 Design rules for quasi-linear nonlinear optical structures [9564-7]

ULTRAFAST SPECTROSCOPY AND INFRARED PROPERTIES

$95640 \mathrm{~A}$ Optical and magnetic probes of hot singlet exciton fission in $\pi$-conjugated polymers for organic photovoltaic applications (Invited Paper) [9564-9]

9564 OD Narrow band gap conjugated polymers for emergent optoelectronic technologies (Invited Paper) [9564-12]

NONLINEAR OPTICAL DEVICE DESIGN AND FABRICATION

9564 OF Optical switching with sign control using a nonlinear layer structure [9564-14]

PHOTO-MECHANICS, LIGHT-TRIGGERED, AND LIGHT-ACTUATED MATERIALS I

9564 OK Study on visible-light-curable polycarprolactone and poly(ethylene glycol) diacrylate for LCD-projected maskless additive manufacturing system [9564-19]

$9564 \mathrm{OL}$ Light manipulating vector polyphotochromatic behavior in organic polarization-sensitive materials [9564-20]

PHOTO-MECHANICS, LIGHT-TRIGGERED, AND LIGHT-ACTUATED MATERIALS II

9564 OM Visible light responsive systems based on metastable-state photoacids (Invited Paper) [9564-21] 
$9564 \mathrm{ON}$ Characterization of photomechanical elastomers for device applications [9564-22]

$956400 \quad$ Modeling fiber Bragg grating device networks in photomechanical polymer optical fibers [9564-23]

PHOTOREFRACTIVE MATERIALS AND APPLICATIONS

$95640 Q \quad$ Advances in photorefractive polymers and applications (Invited Paper) [9564-25]

9564 OR Electrostatic modification of ZnSe/polymer interface in polymer-nematogen composite and its impact on photorefractive hologram [9564-26]

9564 OS Photopolymerizable polymer nanocomposites incorporated with hyperbranched polymer having ultrahigh index of refraction for holographic light manipulation [9564-27]

9564 OT Photorefractive amplification of moving light signals by photoconductive ferroelectric liquid crystal blends [9564-28]

\section{POSTER SESSION}

9564 OW Growth and characterization of a new nonlinear optical organic crystal: 2,4,6-Trimethylacetanilide [9564-31]

9564 OX Study of large nonlinear change phase in Hibiscus Sabdariffa [9564-32]

9564 OY Photorefractive polymer device with improved sensitizing property [9564-33]

$9564 \mathrm{OZ}$ Effect of metal films on the photostabilities of emissive organic layers as probed by fluorescence microscopy [9564-34] 


\title{
Authors
}

Numbers in the index correspond to the last two digits of the six-digit citation identifier (CID) article numbering system used in Proceedings of SPIE. The first four digits reflect the volume number. Base 36 numbering is employed for the last two digits and indicates the order of articles within the volume. Numbers start with 00, 01, 02, 03, 04, 05, 06, 07, 08, 09, 0A, 0B...0Z, followed by 10-1Z, 20-2Z, etc.

\author{
Abbas, Sikandar, $\mathrm{OZ}$ \\ Alvarado-Méndez, E., OX \\ Andrade-Lucio, J. A., OX \\ Azoulay, Jason D., OD \\ Bernhardt, Elizabeth A., ON \\ Blanche, P.-A., $0 Q$ \\ Chaganava, Irakli, OL \\ Cheng, Yih-Lin, OK \\ Dawson, Nathan J., 06 \\ Fu, Jiayin, OR \\ Fukamizu, Taka-aki, OS \\ Garrison, Chad M., ON \\ Giang, Ha N., OY \\ Gross, Richard A., 06 \\ Hu, Guangwei, OR \\ Kakauridze, George, OL \\ Kametani, Yasuhiro, OS \\ Kao, Hao-Lun, OK \\ Kilosanidze, Barbara, OL \\ Kinashi, K., OY \\ Kuzyk, Mark G., 08, 0N, 00 \\ Lanska, Joseph T., ON, 00 \\ Liang, Zi, OF \\ Liao, Yi, OM \\ London, Alexander E., OD \\ Lynn, B., OQ \\ Lytel, Richard, 08 \\ Maiorana, Anthony, 06 \\ Mossman, Sean M., 08 \\ Nguyen, Tam $\mathrm{V}_{\text {., }} \mathrm{OY}$ \\ Nishimura, Naoya, OS \\ Norwood, R. A., OQ \\ Odi, Keisuke, OS \\ Olejnik, Ella, OA \\ Palffy-Muhoray, Peter, ON \\ Perez-Moreno, Javier, 07 \\ Peteanu, Linda A., $0 Z$ \\ Peters, Kyle C., 06 \\ Pevnyi, Mykhailo Y., ON \\ Peyghambarian, N., $0 Q$ \\ Prabhu, Sharada G., OW \\ Rasmussen, Nathan F., ON \\ Rojas-Laguna, R., OX \\ Sakai, W., OY \\ Sasaki, Takeo, OT \\ Singer, Kenneth D., 06 \\ Spinella, Stephen, 06 \\ Sullivan, Dennis M., 00 \\ Tomita, Yasuo, OS
}

Trejo-Durán, M., OX

Tsutsumi, N., OY

Upadhyaya, V., OW

Urano, Hiroshi, OS

Vardeny, Z. Valy, OA

Vázquez-Guevara, M. A., OX

Wu, Pengfei, OF

Yoshino, Masanori, OT

Zhai, Yaxin, OA

Zhang, Benjamin A., OD

Zhang, Jingwen, $O R$

Zhao, Hua, OR 
Proc. of SPIE Vol. $9564956401-6$

Downloaded From: https://www.spiedigitallibrary.org/conference-proceedings-of-spie on 26 Apr 2023 Terms of Use: https://www.spiedigitallibrary.org/terms-of-use 


\section{Conference Committee}

Symposium Chair

Zakya H. Kafafi, Lehigh University (United States)

Conference Chair

Jon A. Schuller, University of California, Santa Barbara (United States)

Conference Co-Chairs

Rachel Jakubiak, Air Force Research Laboratory (United States)

Manfred Eich, Technische Universität Hamburg-Harburg (Germany)

Jean-Michel Nunzi, Queen's University (Canada)

Conference Program Committee

Dean R. Evans, Air Force Research Laboratory (United States)

Theodore G. Goodson III, University of Michigan (United States)

Mark G. Kuzyk, Washington State University (United States)

Charles Y. C. Lee, Air Force Office of Scientific Research (United States)

Kwang-Sup Lee, Hannam University (Korea, Republic of)

André P. Persoons, Katholieke Universiteit Leuven (Belgium)

Zouheir Sekkat, Moroccan Foundation for Advanced Science, Innovation and Research (Morocco)

Matthew Y. Sfeir, Brookhaven National Laboratory (United States)

Jayan Thomas, CREOL, The College of Optics and Photonics, University of Central Florida (United States)

Naoto Tsutsumi, Kyoto Institute of Technology (Japan)

\section{Session Chairs}

1 Exciton-Polaritons and Organic Plasmonics

Jon A. Schuller, University of California, Santa Barbara (United States)

2 Nonlinear Processes and Materials

Timothy J. White, Air Force Research Laboratory (United States)

3 Ultrafast Spectroscopy and Infrared Properties

Matthew Y. Sfeir, Brookhaven National Laboratory (United States)

4 Nonlinear Optical Device Design and Fabrication

Jon A. Schuller, University of California, Santa Barbara (United States) 
5 Photo-mechanics, Light-triggered, and Light-actuated Materials I Yi Liao, Florida Institute of Technology (United States)

6 Photo-mechanics, Light-triggered, and Light-actuated Materials II Zouheir Sekkat, Moroccan Foundation for Advanced Science, Innovation and Research (Morocco)

7 Photorefractive Materials and Applications

Mark G. Kuzyk, Washington State University (United States) 